\title{
GAMBARAN INFEKSI SOIL TRANSMITTED HELMINTH PADA PETANI DI DESA GELGEL KABUPATEN KLUNGKUNG
}

\author{
${ }^{1}$ Putu Indah Budi Apsari*, Ni Wayan Winianti, ${ }^{2}$ Heny Arwati, ${ }^{2}$ Yoes Prijatna Dachlan \\ ${ }^{1}$ Fakultas Kedokteran dan Ilmu Kesehatan Universitas Warmadewa, ${ }^{2}$ Fakultas Kedokteran Universitas \\ Airlanggga \\ *Corresponding author: putuindah51@yahoo.com
}

\begin{abstract}
Soil transmitted helminth (STH) infections is kind of helminth infection which transmitted by contact with warm and moist soil especially affect the farmer. The purpose of this study was to investigate the profile of STH infection and the intensity of STH infection among farmers in Gelgel Village, Klungkung, Bali.

Methods: The cross sectional study was conducted in Gelgel Village, Klungkung District, Bali and obtained stool and quitionaires from farmers by informed consent. Kato-Katz technique was used to diagnose the STH infection and to determine the intensity of infection based on the number of eggs per gram feces (EPG).

Results: Total 162 stool samples were collected from farmers aged 25-80 years, 22 farmers was positive of STH infection and 140 farmers was negative of STH infection. The result showed prevalence of STH infection was $13,5 \%$, single infection of A. lumbricoides was $1.85 \%, 9.26 \%$ of $T$. trichiura single infection, and $0.61 \%$ of Hookworm single infection. The mixed infection was detected that were $1.23 \%$ of A. lumbricoides with T. trichiura, and $0.61 \%$ of A. lumbricoides with Hookworm.
\end{abstract}

Conclusion: STH infection is the health problem among farmer. The farmer must be admitted antihelminthic drugs for preventing and eleminating STH infection.

Keywords: Soil, transmitted, helmith, farmer

\section{PENDAHULUAN}

Soil Transmitted Helminths (STH) adalah suatu kelompok parasit Nematoda yang menyebabkan infeksi pada manusia melalui kontak dengan telur parasit atau larva yang berkembang di dalam tanah yang hangat dan lembab. ${ }^{1,2}$ Infeksi STH masih merupakan masalah di daerah endemis di berbagai belahan dunia, terutama di negara yang sedang berkembang dengan sanitasi lingkungan dan kebersihan diri yang sangat kurang. ${ }^{3}$ Menurut WHO pada tahun 2017, lebih dari 1,5 miliar manusia atau $24 \%$ dari total populasi seluruh dunia terinfestasi STH. ${ }^{4}$ Infeksi tersebar di daerah tropis dan subtropis termasuk Indonesia dengan jumlah terbanyak pada daerah subSahara, Afrika, Amerika, China dan Asia. Spesies STH yang paling sering menginfeksi 
manusia adalah Ascaris lumbricoides (cacing gelang), Trichuris trichiura (cacing cambuk) dan hookworm atau cacing tambang (Ancylostoma duodenale dan Necator americanus). ${ }^{4,5}$

Prevalensi infeksi STH pada petani di Vietnam adalah 24\% A. lumbricoides, $40 \%$ T.trichiura dan 2\% Hookworm. ${ }^{6}$ Pada penelitian yang dilakukan di Ghana, didapatkan prevalensi infeksi STH pada petani pada musim hujan yaitu 15,77\% A. lumbricoides, 12,73\% Hookworm. ${ }^{7}$ Di Indonesia pada penelitian yang dilakukan di Kabupaten Kediri, Jawa timur, prevalensi infeksi A. lumbricoides pada petani sebanyak 40\%, T.trichiura dan Hookworm masing-masing $0,025 \% .^{8}$

Di provinsi Bali, berdasarkan penelitian yang dilakukan di Laboratorium Parasitologi Universitas Udayana pada kurun waktu tahun 2004-2011, menyatakan bahwa prevalensi STH pada penduduk pedesaan di Bali relatif tinggi, yaitu 35\% positif horkworm, 63\% T. trichiura, dan 74\% A. lumbricoides. Pada tahun 2004 penelitian lain yang dilakukan pada $37 \mathrm{SD}$ di daerah Singaraja, Badung, Denpasar, Klungkung, Gianyar dan Bangli, menunjukkan rata-rata prevalensi infeksi STH sekitar 58,3\% $-96,8 \% .^{9}$

Pada penelitian yang dilakukan di Ghana, petani tiga kali lebih berisiko terinfeksi STH dibandingkan bukan petani $(\mathrm{OR}=3,99,95 \% \mathrm{CI}$ : 1,15-13,86). ${ }^{7}$ Selain menyerang anak-anak, STH dapat menyerang orang dewasa dengan pekerjaan tertentu yang berhubungan dengan tanah seperti petani, peternak, pekerja pengolah pupuk kandang, pekerja tanah liat dan lain sebagainya. $^{10}$ Di Kabupaten Klungkung penduduk miskin yang bekerja pada sektor pertanian dan peternakan pada tahun 2015 sebanyak 54\% paling tinggi di antara kabupaten lain di Bali. ${ }^{11}$ Tingginya jumlah tenaga kerja sektor pertanian di Kabupaten Klungkung tidak dibarengi dengan peningkatan kualitas kesehatan. Tidak ada data kesehatan khusus yang dimiliki oleh para petani dan petani merupakan populasi yang tidak tersentuh oleh program pemberantasan kecacingan oleh pemerintah. ${ }^{12,13}$ Infeksi STH pada manusia dapat menyebabkan gangguan pada jaringan dan organ tubuh, tempat parasit tersebut hidup dan mengambil nutrisi dari dalam tubuh manusia. Morbiditas STH ini menyebabkan infeksi, kemiskinan, penurunan produktivitas dan sosial ekonomi yang rendah terus berlanjut. $^{4}$

\section{METODE PENELITIAN}

Penelitian cross sectional analitik ini dilakukan di Desa gelgel Kabupaten Klungkung, periode Desember sampai Januari 2017. Sampel penelitian ini adalah petani aktif baik laki-laki maupun wanita yang bersedia mengikuti penelitian dengan menandatangani informed consent. Sampel kemudian dipilih secara simple random sampling sampai tercapai jumlah minimum yang diinginkan. ${ }^{14}$ Wawancara terstruktur menggunakan kuisioner digunakan untuk mengumpulkan data demografi responden. Sampel feses dikumpulkan di dalam tabung berukuran $50 \mathrm{ml}$ dengan tutup berwarna kuning sebanyak 2-5 gram. Sampel feses kemudian ditambahkan 
formalin $10 \%$ sebagai pengawet dan diletakkan di kotak penyimpan sebelum di bawa ke laboratorium. ${ }^{15}$ Metode Kato-Katz digunakan untuk mendiagnosis infeksi STH dan menentukan intensitas infeksi yang ditetapkan berdasarkan jumlah telur per gram feses (EPG). ${ }^{16,17}$

\section{HASIL PENELITIAN}

Kabupaten Klungkung merupakan kabupaten dengan wilayah geografis terkecil dari sembilan kabupaten/kota di wilayah Provinsi Bali. Kabupaten Klungkung wilayahnya terbagi menjadi dua bagian yaitu Klungkung Daratan dan Klungkung Kepulauan. Secara administrasi Kabupaten Klungkung mewilayahi 4 kecamatan dengan 59 desa/kelurahan dengan luas wilayah kurang lebih $315 \mathrm{Km}^{2}$. Kecamatan terluas adalah Kecamatan Nusa Penida yang berada di Klungkung Kepulauan dengan luas wilayah dua pertiga dari luas Kabupaten Klungkung $\left(202,84 \mathrm{Km}^{2}\right)$ sedangkan tiga kecamatan dengan luas wilayah 112,16 $\mathrm{Km}^{2}$ berada di Klungkung Daratan yaitu Kecamatan Klungkung, Banjarangkan dan Kecamatan Dawan. ${ }^{12}$

Secara geografis, Kabupaten Klungkung terletak pada posisi titik ordinat: $115021^{\prime} 28$ ' 1150 37' 43" Bujur Timur, dan 0080 27' 37” 0080 49' 00" Lintang Selatan dengan batasbatas di sebelah Utara Kabupaten Bangli, sebelah Timur Kabupaten Karangasem, sebelah Selatan Samudra Hindia dan sebelah Barat Kabupaten Gianyar. Seperti daerah tropis lainnya, Kabupaten Klungkung memiliki 2 musim yaitu musim hujan dan musim kemarau.
Musim hujan terjadi pada Bulan September sampai dengan April dengan puncaknya sekitar Oktober dan Desember. Namun demikian terdapat perbedaan curah hujan yang sangat menjolok antara wilayah kepulauan Nusa Penida dengan wilayah Klungkung Daratan. Perbedaan curah hujan ini berpengaruh terhadap pemanfaatan lahan pertanian yang berdampak langsung terhadap perkonomian masyarakat disamping kemungkinan berpengaruh terhadap pola penyakit yang berkaitan dengan kondisi tanah yang lembab dan hangat seperti cacing yang ditularkan lewat $\operatorname{tanah}(\mathrm{STH})^{12}$

Provinsi Bali masih termasuk daerah endemis STH sama seperti daerah lain di Indonesia. Penelitian yang dilakukan oleh Widjana et al (2000), prevalensi STH pada penduduk pedesaan $73,7 \%$ A. lumbricoides, 62,6 T. trichiura, 24,5\% Hookworm. ${ }^{5}$

\section{Karakteristik Subjek Penelitian}

Selama periode penelitian Desember 2017 sampai Januari 2018, sebanyak 250 populasi petani aktif di desa Gelgel terpilih sebagai sampel dengan metode simple random sampling. Sebanyak 162 subjek menyerahkan kuisioner lengkap dengan sampel tinja, sisanya sebanyak 48 subjek tidak menyerahkan sampel tinja dan kuisioner Kelompok positif STH memiliki rerata umur subjek 55,59 tahun dan kelompok negatif STH 55,11 tahun. Lama kerja kelompok prositif STH rerata 21,9 tahun, sedangkan kelompok negatif STH rerata 20,7 tahun. Jam kerja kelompok positif STH rerata 9,1 jam dan kelompok negatif STH rerata 8,6 jam. Berdasarkan jenis kelaminnya, kelompok 
positif STH berjenis kelamin laki-laki sebanyak 12 orang $(54,5 \%)$ dan perempuan sebanyak 10 orang $(45,5 \%)$, kelompok negatif STH berjenis kelamin laki-laki 90 orang $(64,3 \%)$ dan perempuan 50 orang $(35,7 \%)$. Sebagian besar kelompok positif STH tidak bersekolah dan hanya tamat SD masing-masing 9 orang $(40,9)$, sedangkan kelompok negatif STH sebagian besar tamat SD 70 orang $(50,0 \%)$. Sebagian besar penghasilan kelompok positif STH dibawah 250 ribu, sama halnya dengan kelompok negatif STH sebagian besar berpenghasilan dibawah 250 ribu. Sebagian besar petani juga bekerja sebagai peternak baik pada kelompok positif STH 17 orang $(77,3 \%)$, maupun kelompok negatif STH 117 orang $(83,6 \%)$.

Tabel 1. Karakteristik subjek penelitian

\begin{tabular}{lcc}
\hline Karakteristik petani & Positif STH $(\mathrm{n}=22)$ & Negatif STH $(\mathrm{n}=140)$ \\
\cline { 2 - 3 } & Jumlah(\%) & Jumlah(\%) \\
\hline Umur (tahun); rerata \pm SD & $55,59 \pm 8,1$ & $55,11 \pm 10,9$ \\
Jenis kelamin & & $90(64,3)$ \\
Laki-laki & $12(54,5)$ & $50(35,7)$ \\
Perempuan & $10(45,5)$ & \\
Tingkat Pendidikan & & $39(27,9)$ \\
Tidak Sekolah & $9(40,9)$ & $70(50,0)$ \\
Tamat SD & $9(40,9)$ & $12(8,6)$ \\
Tamat SMP & $1(4,5)$ & $18(12,9)$ \\
Tamat SMA & $3(13,6)$ & $1(0,7)$ \\
Tamat PT & $0(0)$ & $20,7 \pm 13,8$ \\
Lama kerja (tahun); rerata \pm SD & $21,9 \pm 11,4$ & $8,6 \pm 1,7$ \\
Jam kerja (jam): rerata \pm SD & $9,1 \pm 1,6$ & \\
Jumlah Penghasilan per bulan & & $72(51,4)$ \\
$<250 r b$ & $12(54,5)$ & $62(44,3)$ \\
$500-<1 j t$ & $10(45,5)$ & $6(4,3)$ \\
$>1 j t$ & $0(0)$ & $23(16,4)$ \\
Kepemilikan ternak & $17(77,3)$ & \\
Ya & $5(22,7)$ & \\
Tidak & & \\
\hline
\end{tabular}




\section{Prevalensi infeksi STH pada Petani}

Sebanyak 162 sampel feses yang diperiksa, terdapat 22 sampel positif terinfeksi STH dan sebanyak 140 sampel negatif infeksi STH sehingga didapatkan prevlensi infeksi STH pada petani adalah 13,5\%. Prevalensi spesies tertinggi adalah T. trichiura sebanyak $15(9,26 \%)$ sampel, diikuti oleh A. lumbricoides
3 (1,85\%) sampel, Hookworm 1 (0,61\%) sampel dan infeksi campuran masing-masing A.lumbricoides dan Hookworm 1 (0,61\%) dan A.lumbricoides dan T.trichiura 2 (1,23\%) sampel. Berikut ini merupakan hasil identifikasi spesies menggunakan morfologi telur di bawah mikroskop cahaya.

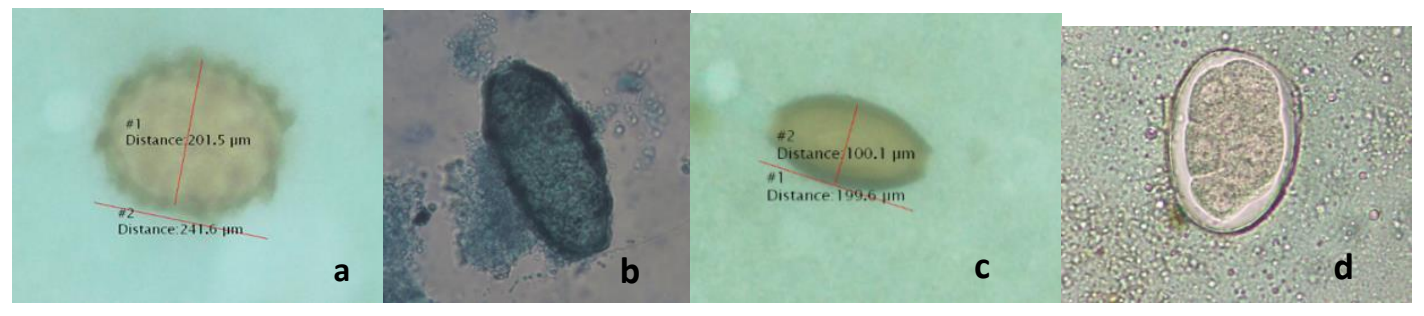

Gambar 1 Morfologi telur A. lumbricoides,(a) telur fertil, (b) telur infertil, pada infeksi tunggal, (c) Telur Trichuris trichiura, (d) telur Hookworm, diamati menggunakan pembesaran lensa objektif 40x mikroskop merk Olympus, Tokyo, Japan

Tabel 2. Rerata jumlah telur per gram feses (EPG) pada petani yang terinfeksi STH di Kabupaten Klungkung

\begin{tabular}{lcc}
\hline Spesies & n(\%) & EPG (rerata \pm SD) \\
\hline A. lumbricoides & $3(13,6)$ & $160 \pm 176$ \\
T. trichiura & $15(68,1)$ & $53,5 \pm 27,9$ \\
Hookworm & $1(4,5)$ & 48 \\
A.lumbricoides + T.trichiura & $2(9)$ & $132 \pm 118$ \\
A.lumbricoides + Hookworm & $1(4,5)$ & 144 \\
\hline
\end{tabular}

Data yang ditunjukkan pada tabel 2, rerata EPG yang paling tinggi adalah pada infeksi tunggal A. lumbricoides sebanyak 160 butir telur per gram feses, kemudian infeksi campuran A.lumbricoides + Hookworm sebanyak 144 butir telur per gram feses, infeksi campuran
A.lumbricoides + T.trichiura 132 butir telur per gram feses, sedangkan infeksi tunggal Hookworm 48 butir telur dan T. trichiura 53,3 butir telur per gram feses. Intensitas infeksi menurut WHO (2017) seluruhnya adalah intensitas infeksi ringan. 


\section{PEMBAHASAN}

\section{Karakteristik subjek penelitian}

Pada penelitian ini diketahui bahwa infeksi STH masih menjadi masalah bagi populasi di daerah pedesaan. Jenis kelamin laki-laki adalah yang paling banyak terinfeksi STH dibandingkan perempuan. Hasil yang berbeda ditunjukkan oleh Pham-duc et al (2013), yaitu didapatkan bahwa jumlah perempuan yang positif STH lebih tinggi daripada laki-laki, tetapi berdasarkan hasil uji Chi-square, tidak terdapat perbedaan risiko antara jenis kelamin laki-laki dibandingkan perempuan. Hal tersebut berarti bahwa jenis kelamin mempunyai risiko yang sama untuk terkena infeksi. ${ }^{6}$

\section{Prevalensi infeksi STH dan intensitas infeksi pada kelompok positif STH}

Prevalensi setiap spesies pada petani menunjukkan perbedaan yang bervariasi. Prevalensi A.lumbricoides pada penelitian ini lebih rendah daripada penelitian sebelumnya oleh Amoah et al (2016) di Kumasi, Ghana. Hal ini dapat disebabkan oleh karena kondisi tanah yang berbeda pada setiap tanah yang mempengaruhi ketahanan hidup telur STH. Di Klungkung kondisi tanah cukup kering dengan irigasi yang kurang karena letusan lahar dingin Gunung Agung, irigasi lahan bergantung sepenuhnya dari air hujan. ${ }^{7,18}$

Prevalensi infeksi T.trichiura yang tinggi pada penelitian ini sesuai dengan penelitian yang dilakukan oleh Pham-duc et al (2013) di Hanoi, Vietnam. Tingginya prevalensi
T.trichiura pada daerah penelitian ini disebabkan oleh hospes yang merupakan orang dewasa cenderung mengalami infeksi persisten dan kronis. Ditemukan peran rumah tangga (household) yang berada dalam satu pekarangan terhadap transmisi infeksi $T$. trichiura pada penelitian ini. Penularan antar anggota keluarga berkaitan dengan kesamaan lingkungan, perilaku hidup bersih dan sehat yang kurang, makanan yang dimakan bersamasama dan kebiasaan tidak menggunakan sarung tangan, alas kaki serta baju pelindung saat bekerja di sawah. Orang yang tinggal dalam satu pekarangan dapat tertular satu sama lain, misalnya anak dengan ibu, ayah dengan ibu atau saudara ipar, kakek dan nenek. ${ }^{7,19}$ Hasil studi Bopda et al (2016) di Akonolinga, Cameroon, menyatakan infeksi STH yang paling tinggi pada orang dewasa adalah T.trichiura. $^{20}$ Risiko pekerjaan yang berhubungan dengan tanah mengakibatkan paparan terus berulang. Orang dewasa adalah kelompok yang tidak tersentuh oleh pengobatan masal antihelminth, hal ini dapat menjadi sumber penyebaran infeksi dan reservoir bagi spesies STH. ${ }^{9}$ Hasil studi di Mbeya, Tanzania (2017) prevalensi T.trichiura yang tinggi berkaitan dengan kepadatan tumbuh-tumbuhan dan sayur-sayuran oleh karena tumbuhan atau sayuran memberi keteduhan, melindungi telur dari radiasi sinar ultraviolet matahari dan kondisi kering, serta membuat kondisi tanah lebih lembab, kondisi yang sangat dibutuhkan untuk perkembangan telur T.trichiura. ${ }^{21}$

Prevalensi Hookworm pada penelitian ini tidak jauh berbeda dengan penelitian yang 
dilakukan oleh Ensink et al (2005) di Pakistan. Hal ini disebabkan oleh kesamaan geografis lokasi penelitian berada dalam wilayah tropis, dengan kondisi tanah yang lembab dan hangat. Populasi penelitian merupakan penduduk miskin dengan sanitasi buruk, mirip dengan penelitian ini. ${ }^{22}$

Rentang EPG pada penelitian ini berkisar diantara 48-160, hasil ini sesuai dengan penelitian yang dilakukan oleh Amoah et al (2016) dengan rata-rata jumlah telur per gram feses pada musim hujan 4-223 dan pada musim kering 3-124. 7,22,23 Kesamaan hasil tersebut dikarenakan subjek yang digunakan memiliki kemiripan dengan penelitian ini. Petani padi, sayuran dan palawija di Desa Gelgel sama dengan petani sayur yang dijadikan sampel di Kumasi Ghana, dengan pola yang sama dan setiap hari terpapar oleh tanah maka risiko terinfeksi STH akan semakin tinggi. ${ }^{6,711}$ Rerata jumlah EPG tertinggi pada A.lumbricoides sesuai dengan studi literatur yang dikemukakan oleh Farrar et al (2013), bahwa cacing betina A.lumbricoides memproduksi 200.000 telur per hari, paling tinggi dibandingkan dengan T.trichiura maupun Hookworm. ${ }^{23,24,25}$ Ukuran tubuhnya juga paling besar walaupun dalam penelitian ini tidak ditemukan cacing dewasa. Cacing dewasa keluar setelah diprovokasi dengan obat Albendazole $400 \mathrm{mg}$ dosis tunggal. Menandakan bahwa imunitas hospes tidak mampu mengekspulsi cacing keluar dari tubuh pada infeksi STH kronis. Intensitas infeksi STH pada penelitian ini seluruhnya berada dalam kategori ringan sesuai dengan hasil penelitian Amoah et al (2016). ${ }^{7}$ Hal ini dikarenakan infeksi STH pada orang dewasa pada umumnya ringan dan kronis oleh karena jumlah cacing dewasa yang sedikit, maka jumlah telur yang dihasilkan pun jumlahnya akan sedikit. ${ }^{26,27}$ Selain itu maturitas sistem imun pada orang dewasa membuat intensitas infeksi cenderung ringan namun persisten. ${ }^{28,29,30}$

\section{KESIMPULAN}

Prevalensi infeksi pada petani di Desa Gelgel adalah $13,5 \%$ yang termasuk dalam kategori rendah, namun masih merupakan masalah kesehatan yang memerlukan penanganan. Perilaku hidup bersih dan sehat pada petani masih sangat kurang, sehingga perlu edukasi khusus kepada petani tersebut.

\section{SARAN}

Petani merupakan pekerjaan yang sering kontak dengan tanah yang merupakan media penularan STH. Kepada pemegang program kesehatan, pengobatan masal antihelminth juga harus diberikan kepada petani agar terhindar dari infeksi STH kronis yang akan membuat produktivitas dan stamina dalam bekerja menjadi menurun.

\section{UCAPAN TERIMA KASIH}

Ucapan terima kasih kami sampaikan kepada Bupati Klungkung, Dinas Kesehatan abupaten Klungkung, Kepala desa Gelgel dan Dekan Fakultas Kedokteran dan Ilmu Kesehatan Universitas warmadewa yang mendukung sehingga penelitian ini dapat terlaksana dan selesai tepat waktu. Semoga hasil penelitian ini dapat bermanfaat bagi masyarakat dan 
pemegang program kesehatan sebagai data tambahan untuk kebijakan-kebijakan selanjutnya.

\section{DAFTAR PUSTAKA}

1. Apsari, P. I. B.; Arwati, H.; Dachlan, Y. P. 2018. Correlation Of Eosinofil And Basophil Count With Intensity Of Soil Transmitted Helminth Infection Among Farmers In Bali. Iop Conference Series: Materials Science And Engineering, Volume 434, Issue 1, Pp. 012142 (2018).

2. Apsari PIB, Heny Arwati, Yoes Prijatna Dachlan. 2019. Correlation Of Total Ige Level And Intensity Of Infection Among Soil Transmitted Helminthiasis Farmers In Klungkung Regency, Bali, Indonesia. Folia Medica Indonesiana. Vol 55, No 2 (2019)

3. Apsari PIB, Anak agung gede Indraningrat, Heny Arwati, Yoesprijatna Dachlan2short Communication: Prevalence And Risk Factors Of SoilTransmitted Helminth Infection Among Farmers In Gelgel Village, Klungkung District, Bali, Indonesia. Biodiversitas. Volume 21 Number 4 Pp 1535-1540.

4. WHO, 2017. World Health Organization. www.who.int/intestinal_worms (Diakses 16 Agustus 2017).

5. Widjana, D. P. \& Sutisna, P., 2000. Prevalence Of Soil-Transmitted Helminth Infection in the rural population of Bali, Indonesia. Southeast Asian J Trop Med Public Health, 31(3), pp. 454-459.
6. Pham-Duc, P., Nguyen-Viet, H. \& Hattendorf, J., 2013. Ascaris lumbricoides and Trichuris trichiura infections associated with wastewater and human excreta use in agriculture in Vietnam. Parasitology International, Volume 62, pp. 172-180.

7. Amoah, I. D., Abubakari, A. \& Stenstrom, T. A., 2016. Contribution of Wastewater Irrigation to Soil Transmitted Helminths Infection among Vegetable Farmers in Kumasi, Ghana. PLOS Neglected Tropical Diseases, 10(12), pp. 1-12.

8. Kasimo, Elfred S., Arwati, H. \& Suwarno, 2016. Gambaran Basofil, TNF- $\alpha$, dan IL-9 Pada Petani Terinfeksi STH di kabupaten Kediri. Jurnal Biosains Pascasarjana, 18(3), pp. 1-13.

9. Sudarmaja, I., 2011. Epidemologi Infeksi Kecacingan di Bali, Bali: Laboratorium Parasitologi Universitas Udayana.

10. CDC, 2013., Soil Transmitted Helminth. Center of Disease Control and Prevention. www.cdc.gov/parasites/sth (Diakses tanggal 10 September 2017).

11. Biro Humas Provinsi Bali, P. S. D. P. B., 2017. Biro Humas dan Protokol Sekretariat Daerah Provinsi Bali. www.birohumas.baliprov.go.id (Diakses 16 Agustus 2017).

12. Dinas Kesehatan Kabupaten Klungkung., 2015. Profil Kesehatan Kabupaten Klungkung, Klungkung: Pemerintah Kabupaten Klungkung.

13. BPS Kabupaten Klungkung, Pemerintah Daerah Kabupaten Klungkung., 2013. 
Angka Sementara Hasil Sensus Pertanian 2013, Klungkung: Badan Pusat Statistik Kabupaten Klungkung.

14. Sastroasmoro, S. \& Ismael, S., 2014. Dasar-Dasar metodologi Penelitian Klinis. 5 ed. Jakarta: Sagung Seto.

15. WHO, 1991. Basic Laboratory Method in Medical Parasitology. 1 ed. Geneva: World Health Organzation.

16. Speich, B. Ali, Said M; Albonico, Marco; Utzinger, Jung; Keiser, Jennifer., 2015. Quality Control in The Diagnosis of Trichuris trichiura and Ascaris lumbricoides using kato-Katz technique: experienced from three randomized controlled trials. Parasites \& Vector, 8(82), pp. 1-8.

17. Steinbaum, L. Kwong, Laura H.; Ercumen, Ayse; Negash, Makeda S.; Lovely, Amira J.; Njenga, Sammy M.; Boehm, Alexandria B.; Pickering, Amy J.; Nelson, Kara L., 2017. Detecting and enumerating soil-transmitted helminth eggs in soil: New method development and results from field testing in Kenya and Bangladesh. PLOS Neglected Tropical Diseases, 11(4), pp. 1-15.

18. BAPPEDA Kabupaten Klungkung., 2008. Profil Kabupaten Klungkung Tahun 2008, Klungkung: BPS Kabupaten Klungkung.

19. Jourdan, P. M., Lamberton, P. H. L., Fenwick, A. \& Addiss, D. G., 2017. Soil-transmitted helminth infections. Seminar, pp. 1-14.

20. Bopda, J., Nana-Djeunga, H. \& Tenaguema, J., 2016. Prevalence and intensity of human soil transmitted helminth infections in the Akonolinga health district (Centre Region,Cameroon): Are adult hosts contributing in the persistence of the transmission? Parasite Epidemiology and Control, Volume 1, pp. 199-204.

21. Manz, Kirsi M., Clowes, Petra, Kroidi, Inge, Kowuor, Dickens O., Geldmacher, Cristof, Ntinginya, Nyanda E. Maboko, Leonard, Hoelscher, Michael, Saathof, Elmar. 2017. Trichuris ttrichiura infection and its relation to environmental factor in Mbeya region, Tanzania: A crosssectional, population-based study. PLOS One, Volume 12(4), pp. 1-16.

22. Ensink, J. H., Hoek, W. v. d. \& Mukhtarb, M., 2005. High risk of hookworm infection among wastewater farmers in Pakistan. Transactions of the Royal Society of Tropical Medicine and Hygiene, Volume 99, pp. 809-811.

23. Periago, M. RenataC.Diniz; SimoneA.Pinto; Yakovleva, Anna; Oliveira, Rodrigo Correa; J.Diemert, David; M.Bethony, Jeffrey., 2015. The Right Tool for the Job:Detection of Soil Transmitted Helminths in Areas Coendemic for Other Helminths. PLOS Neglected Tropical Diseases, 9(8), pp. 115.

24. Farrar, J., Hotez, P. J. \& Junghanss, T., 2014. Manson's Tropical Disease. 23rd ed. China: Elsevier.

25. Faulkner, Helen, Joseph Turner, Joseph Kamgno, Se 'bastien D. Pion, Michel 
https://ejournal.warmadewa.ac.id/index.php/wicaksana

Boussinesq, and Janette E. Bradley. 2002. Age and Infection Intensity Dependent Cytokine and Antibody Production in Human Trichuriasis: The Importance of IgE. The Journal of Infectious Diseases, Volume 185, pp. 665-672

26. Paniker, C. K. J. \& Gosh, S., 2013. Medical Parasitology. Seventh ed. New Delhi: Jaypee Brothers Mecidal Publishers.

27. Lamberton, P. H. \& Jourdan, P. M., 2015. Human Ascariasis: Diagnostic Update. Curr Trop Med Rep, Volume 3, pp. 1-12.

28. Levecke, B. Behnke, Jerzy M.; Ajjampur, Sitara S. R.; Albonico, Marco; Ame, Shaali M.; Charlier, Johannes; Geiger, Stefan M.; Hoa, Nguyen T. V.; Ngassam, Romuald I. Kamwa; Kotze, Andrew C.; McCarthy, James S.; Montresor, Antonio; Maria V. Periago., 2010. A Comparison of the Sensitivity and Fecal Egg Counts of the McMaster Egg Counting and Kato-Katz Thick Smear Methods for SoilTransmitted Helminths. PLOS Neglected Tropical Disease, 5(6), pp. 1-10.

29. Mofid, L. S., Bickle, Q. \& Jiang, J.-Y., 2011. Soil-transmitted Helminthiasis in Rural South-west China: prevalence, intensity and risk factor analysis. Southeast Asian J Trop Med Public Health, 42(3), pp. 513-526.

30. Apsari PIB. 2018. Hubungan Kadar Ige Total, Jumlah Eosinofil Dan Basofil Dengan Intensitas Infeksi Ascaris Lumbricoides, Trichuris Trichiura Dan Hookworm Pada Petani Di Kabupaten Klungkung Provinsi Bali. Tesis. Program Pascasarjana Fakultas Kedokteran. Universitas Airlangga. 